\title{
Information Technology and Corporate Governance in Fraud Prevention
}

\author{
Nendi Juhandi ${ }^{1}$, Saefudin Zuhri ${ }^{1}$, Mochammad Fahlevi ${ }^{2 *}$, Rinto Noviantoro ${ }^{3}$, Muhammad \\ Nur abdi ${ }^{4}$, Setiadi ${ }^{5}$ \\ ${ }^{1}$ Management Department, Kusuma Negara Business School, Jakarta, Indonesia \\ ${ }^{2}$ Management Department, BINUS Online Learning, Bina Nusantara University, Jakarta, Indonesia \\ 11480 \\ ${ }^{3}$ Accounting Department, Dehasen University, Bengkulu, Indonesia \\ ${ }^{4}$ Finance Department, Muhammadiyah Makassar University, Makassar, Indonesia \\ ${ }^{5}$ Accounting Department, Dirgantara Marsekal Suryadarma University, Jakarta, Indonesia
}

\begin{abstract}
Information technology is a technology for obtaining, processing, storing and distributing various types of information files by utilizing computers and telecommunications born of strong drives to create new innovations and creativity that can overcome all laziness and slowness of human performance. The recent phenomenon of several large companies listed on the Indonesia Stock Exchange shows that there is an improper management of the company, especially in supervision, thereby reducing the value of the company. The result is proven that developed companies, especially in developed countries, use supervision not only as a leader but also technology that can automatically detect fraud and is useful as a step to prevent fraud in companies. Corporate governance is still lacking in Indonesia and other developing countries, making the level of supervision at the company does not run optimally so that the potential for fraud is still quite large. This research contributes to fill the void level of supervision in companies in Indonesia that are still experiencing fraud, so the solution in supervision is to maximize the role of information technology in companies in Indonesia.
\end{abstract}

Keywords. Information, Technology, Corporate Governance, Fraud, Indonesia.

\section{Introduction}

Economic globalization is a new challenge especially for developing countries like Indonesia, because everything is interrelated and has a special impact such as the occurrence of a crisis that is evenly distributed in each country. For this reason, improving corporate governance is important. Governance can have a positive effect if managed properly. A study conducted by the Asian Development Bank (ADB), identified that the main cause of the

*Corresponding author: mochammad.fahlevi@binus.ac.id 
economic crisis was weak "corporate governance" [1]. This, encourages countries in Asia to improve corporate governance performance is no exception in Indonesia.

There are several reasons for choosing Indonesia for this study. First, despite extensive research on the role of corporate governance and information technology in fraud prevention and detection in developed countries[2-10], to the researchers' best knowledge, few empirical studies [11,12] have been conducted on this issue in the UAE. The extensive findings about developed countries may not be applicable to emerging countries because of differences in culture, society, institutional settings, legal systems and economies.

Indonesia's economic growth in scale and corporate activity has increased immeasurably, attention to the implementation of corporate governance is becoming more important, companies need to set a framework to ensure that their activities are in line with governance. In addition, corporate governance has another meaning, namely as a work method in which the company is controlled and directed. This is about the relationship between shareholders and stakeholders. Information disclosure, high transparency and accountability are important elements of the foundation of good corporate governance that strives for the sustainability of the company and society. By implementing good corporate governance practices, companies are believed to be able to increase access to capital, to operate more efficiently, to avoid mismanagement, and to reduce risk and protect stakeholders.

Fraud to date is one thing that is very phenomenal, both in developing countries and in developed countries. Fraud is fraud which implies an irregularity and illegal act, which is done intentionally for a specific purpose, for example deceiving or giving a misleading picture to other parties, committed by people, both from within and from outside the organization [13].

Fraud prevention, namely by describing means of control. The means of control are to create policies, procedures, organizations, control techniques, and employee participation. One effort to prevent fraud that can be done by companies in protecting themselves from data theft is to use anti-virus and update it regularly, and by developing special security systems and applications[13].

Information technology is a technology for obtaining, processing, storing and distributing various types of information files by utilizing computers and telecommunications born of strong drives to create new innovations and creativity that can overcome all laziness and slowness of human performance[14].

The recent phenomenon of several large companies listed on the Indonesia Stock Exchange shows that there is an improper management of the company, especially in supervision, thereby reducing the value of the company. In the case of Jiwasraya which is a state-owned company the Chairman of the BPK found that there was a practice of profit manipulation which caused the company to suffer a loss of up to Rp. 15.3 trillion (CNBC Indonesia, 2020). In other cases, the financial statements of three large state-owned companies such as PT. Garuda Indonesia, PT. The State Electricity Company, and PT Pertamina, the three state-owned companies managed to record a very good performance at the end of 2018, although recorded financial reports in the third quarter of 2018 are still fairly poor (CNN Indonesia, 2019). 


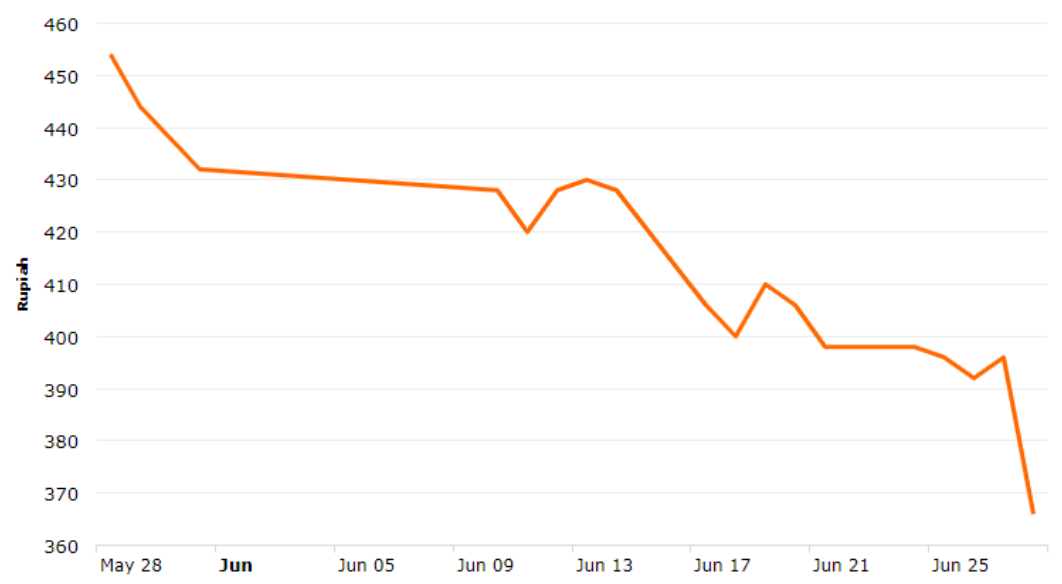

Fig. 1. Garuda Stock Rate (GIAA) May-June 2019

In the graph above it can be seen that Garuda Indonesia shares closed down by $7.58 \%$ at the price of Rp. 366 per share, this contrasts sharply with the share price in May, which was valued at over Rp. 450 per share.

Manipulation in financial statements is a form of fraud that results in a decrease in the quality of financial statements. There is an increased opportunity to engage in financial statement fraud because the company's control structure is weak, corporate governance is ineffective, and the quality of the audit function is poor, thus allowing the company's financial flow to be misused by fraudsters[15], and influencing irrelevant financial reporting [16]. Concluded that the delay in the submission of financial statements related to the audit process in identifying, investigating and resolving problems of fraud and manipulation of financial statements that occur in the company [17].

Asymmetry of information that occurs within the company causes agency conflict so that effective supervision is needed by parties related to company management. Supervision needed by the company is carried out through good corporate governance mechanisms. Good corporate governance mechanisms are able to protect shareholders and creditors so they believe that they will get a return on their investment. Correspondingly, many organizations support their corporate governance mechanisms by implementing an independent board of directors.

Based on the phenomenon that occurred not long ago that rampant practices of fraud in the form of profit manipulation were found by several large companies both state-owned companies and private companies. This can reduce the level of trust of the company by the shareholders and will result in a decrease in the value of the company.

The regulations are quite good, there are still gaps that can be used by leaders to manipulate financial statements for certain purposes that are temporary and detrimental to the company, especially shareholders because the company is not well managed by company leaders. This research will try to answer the role of corporate governance and information technology in fraud prevention in companies in Indonesia. 


\section{Literature Review}

\section{A. Information Technology}

Information technology is defined as technology for obtaining, processing, storing and distributing various types of information files by utilizing computers and telecommunications born from strong drives to create new innovations and creativity that can overcome all laziness and slowness in performance human[14]. From some of the definitions above, it can be concluded that information technology is technology in the form (hardware, software, people) that is used to obtain, transmit, process, interpret, store, organize, and use data meaningfully to obtain quality information.

Technology is a tool or objects needed by the community to meet their needs. Information technology is a technology that is used to process data, including processing, obtaining, compiling, storing, manipulating data in various ways to produce quality information, namely information that is relevant, accurate and timely, which is used for personal, business, and government purposes and is strategic information for decision making [18].

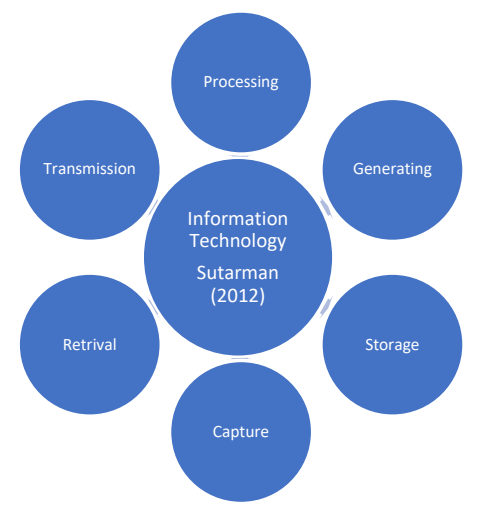

Fig. 2. Information Technology Function, Sutarman (2012)

The purpose of information technology, which is to solve problems, to open creativity, and to increase effectiveness and efficiency at work [19]. The reasons for the application and management of information technology become an important part, namely the increasing complexity of management tasks, the influence of the international economy (globalization), the need for faster response times, and the pressure due to competition business [19].

\section{B. Corporate Governance}

Corporate governance is defined as the system in which the company is directed and controlled. The definition of corporate governance identifies the distribution of rights and responsibilities among various contributors in organizations such as boards, managers, shareholders, and other stakeholders. The corporate governance structure states several rules and procedures for decision making, and company goals are also set in the corporate governance structure. A 'good' corporate governance system ensures that the company sets the right goals and puts in place a system and structure to ensure that these goals are met, it is considered as a tool for all shareholders to control and monitor the activities of the company [20].

As a concept, Good Corporate Governance does not have a single definition. [21] issued its own definition of Good Corporate Governance. According to the Cadbury Committee, 
Good Corporate Governance is the principle that directs and controls the company to achieve a balance between the strength and authority of the company in providing accountability to shareholders in particular and stakeholders in general. Some countries define Good Corporate Governance in slightly similar definitions despite insignificant differences in terminology.

The OECD describes Good Corporate Governance as the way in which company management is accountable to its shareholders. This definition has the same goals as what was defined by the Cadbury Committee [22], defines that corporate governance is part of the larger economic context in which companies operate, which includes macroeconomic policies and the level of competition in product markets and factors. The corporate governance framework also depends on the legal, regulatory and institutional environment. In addition, factors such as business ethics and company awareness of the environmental interests of the community can also have an impact on its reputation and long-term success. In the case of the decision making process, decision makers in the company must be able to take responsibility for their decisions, and the decision itself must be able to provide added value to other stakeholders. Therefore, the OECD's main focus in relation to the company's decision making process must contain the principles of Good Corporate Governance, such as transparency, responsibility, accountability, and fairness.

The Definition of the Corporate Governance Forum in Indonesia (FCGI) on Corporate Governance is similar to the others mentioned earlier. FCGI (2001) defines Good Corporate Governance as a set of rules governing relationships between shareholders, company managers, creditors, the government, employees and other internal and external stakeholders regarding their rights and obligations, or in other words, it is a system which regulates and controls the company. Another definition of Good Corporate Governance comes from the Financial Committee on Malaysian Corporate Governance. According to the agency, Good Corporate Governance is defined as the processes and structures used to direct and manage company business towards increased business growth and corporate accountability. Meanwhile, the Indonesian Corporate Governance Institute (IICG) (2009) defines Corporate Governance as a process and structure that is set up to operate the company with the primary objective of increasing shareholder value in the long term while still considering the interests of other parties. stakeholders in accordance with applicable laws and regulations and norms.

Furthermore, according to The National Committee on Governance Policy [23], Good Corporate Governance is one of the pillars of the market economy system. Corporate Governance is closely related to credibility and trust in both companies that implement it and in the country's business climate. The implementation of Good Corporate Governance encourages the creation of healthy competition and a conducive business climate. The implementation of Good Corporate Governance for companies in Indonesia is very important to support stability and sustainable economic growth. Meanwhile, Good Corporate Governance in accordance with SOE Ministerial Regulation Number: PER-01 / MBU / 2011 concerning Implementation of Good Corporate Governance (GCG) in Government or StateOwned Enterprises (SOEs), are the principles that underlie the process and the company's management mechanism in accordance with law and business ethics.

\section{Fraud}

The Indonesian Institute of Accountants (IAI), explains the definition of fraud (fraud) is every accounting action as: Misstatements arising from fraud in financial reporting that are misstatements or deliberate disappearance of amounts or disclosures in financial statements to deceive users of financial statements and misstatements arising from improper treatment of assets (often referred to as misuse or embezzlement) related to asset theft entities that result in financial statements are not presented in accordance with generally accepted accounting principles in Indonesia. 
Fraud is defined as a broad legal concept, fraud describes any intentional fraud attempt, which is intended to take the assets or rights of people or other parties [24].

Bank Indonesia Circular Letter no 13/28 / DPNP, fraud is an act of deviation or omission that is intentionally done to trick, cheat or manipulate banks, customers, or other parties, which occur within the Bank and / or use Bank facilities so as to cause the Bank, the customer , or another party suffers a loss and / or the fraud perpetrator gains benefits directly or indirectly.

While the Criminal Code (KUHP) mentions several articles that cover the notion of fraud (fraud) are: Article 362 Theft, according to the Criminal Code is to take something, which is wholly or partly owned by another person, with the intention to be owned illegally.

Article 368, Extortion and intimidation, according to the Criminal Code, is to benefit oneself or others unlawfully, force someone with violence or threat of violence to give things away, wholly or partly belonging to that person or others, or to make a debt or write off accounts receivable.

Article 372 Embezzlement, according to the Criminal Code, is deliberate and unlawful possession of something which is wholly or partly owned by another person, but that which is in its power is not due to crime.

Article 378, Deception, according to the Criminal Code, is to benefit oneself or others unlawfully, by using false names or false dignity, by deception, or by a series of lies, moving others to hand over something to him, or to give debt or write off accounts receivable.

Article 396 Harm the creditor in a state of bankruptcy. From some of the definitions above, it can be concluded that fraud is an unlawful act carried out deliberately to achieve certain goals, both carried out individually or in groups, from within and outside the agency to gain profits and harm other parties.

Fraud triangle is a theory put forward by [25]. Cressey found that people commit fraud, when they have financial problems that cannot be solved together, know and believe that the problem can be solved secretly with the position or work they have and change the mindset of their concept as people who are believed to hold assets into their concepts as users of the assets entrusted to them.

Cressey also added that many of these breachers of faith know that the actions they take are illegal, but they try to bring up the notion that what they are doing is a natural action [25].

From the explanation above, Cressey revealed that there are 3 factors that support someone committing fraud, namely: pressure, opportunity, and rationalization.

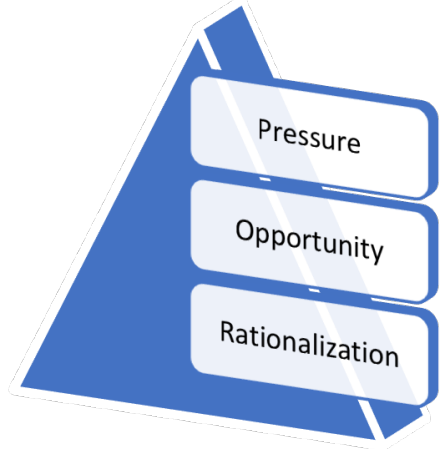

Fig. 3. Fraud Triangle, Cressey (1953). 


\section{Methodology}

This research uses the case study method, the case study is often described as a methodology that is flexible, challenging and most commonly used in social science research. However, support and attention to case studies is the least because there is no well-defined protocol, there is no standardization or formula for how to conduct case study research [26]. Critics of case studies are based that this research cannot provide insight into causality and generalization.

A number of articles with the term "case study" or "case report" are mostly published in medical science, biomedical science, biology and followed by social science and humanities. Although it does not specifically mention psychology, the report is included in the fields of medical science, and / or social science. The case study approach is widely used in clinical cases, with qualitative interpretative or narrative approaches to support single cases that are more quantitative and systematic.

Case studies focus on one particular unit, which can be individuals, groups, organizations, communities. This article will describe and discuss case study research on fraud in Indonesia and explore the use of this methodology in information technology research and corporate governance. This approach is useful for research in developing theories of corporate governance, evaluating fraud prevention programs, and developing interventions because of their flexibility and accuracy [27].

\section{Result and Discussion}

Based on the survey conducted, respondents considered that corruption is the most detrimental type of fraud in Indonesia. As many as 178 respondents or $77 \%$ of all respondents said that corruption was the most detrimental act of fraud in Indonesia.

\section{Fraud in Indonesia}

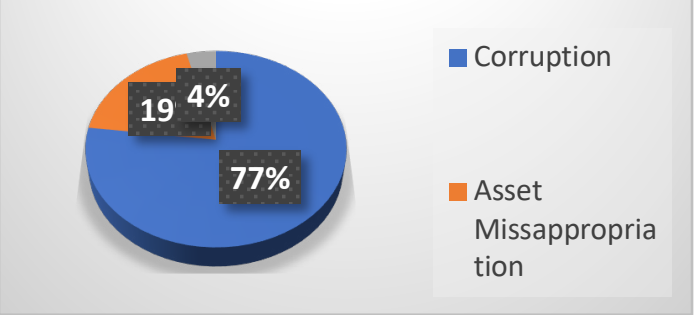

Fig. 4. Survay Fraud Indonesia (2016).

This is different from the survey conducted by [28] which states that fraudulent financial reporting is the most detrimental. This difference is suspected because in Indonesia, various crimes originating from financial statement crimes have not been revealed much, such as information fraud on the stock exchange, as well as crimes due to tax information fraud.

Based on this data it appears that respondents in Indonesia stated that the greatest losses were derived from acts of corruption. In Indonesia no matter what level of loss arises from fraud, losses from corruption are the largest.

Fraud in the form of corruption has a loss mode of IDR 100 million to IDR 500 million. In the graph it is stated that the highest percentage is in the amount of IDR 5 billion to IDR 10 billion, but in a smaller amount.

While it should be noted that despite having the smallest percentage (4\%) overall, the losses caused by financial statement fraud are quite large. This is evidenced from the survey, 
where 4 out of 10 respondents $(40 \%)$ said that losses due to financial statement fraud were above 10 billion rupiah.

The amount of losses due to this type of fraud is different from the results of [28] which states that the largest losses caused by fraud are financial statement fraud amounting to $\$$ $1,000,000$. The reason why fraud losses from this type of corruption are many will be tried to be explained one by one through each of the next indicator items.

Based on Figure 4 it is known that the respondents agreed the report became the media or the main means of finding fraud in Indonesia. The report here is information from internal parties, namely the company's employees. This means that a system is needed that makes the public brave to reveal the existence of fraud. In several institutions in Indonesia, this system already exists, such as the KPK Whistleblowing System, the Director General of the Whistleblowing Tax System, the OJK Whistleblowing System. But the legal umbrella in the form of a law does not yet exist. Therefore, it is necessary to encourage the Whistle-blower Law to more systematically reduce the ranking of corruption in Indonesia.

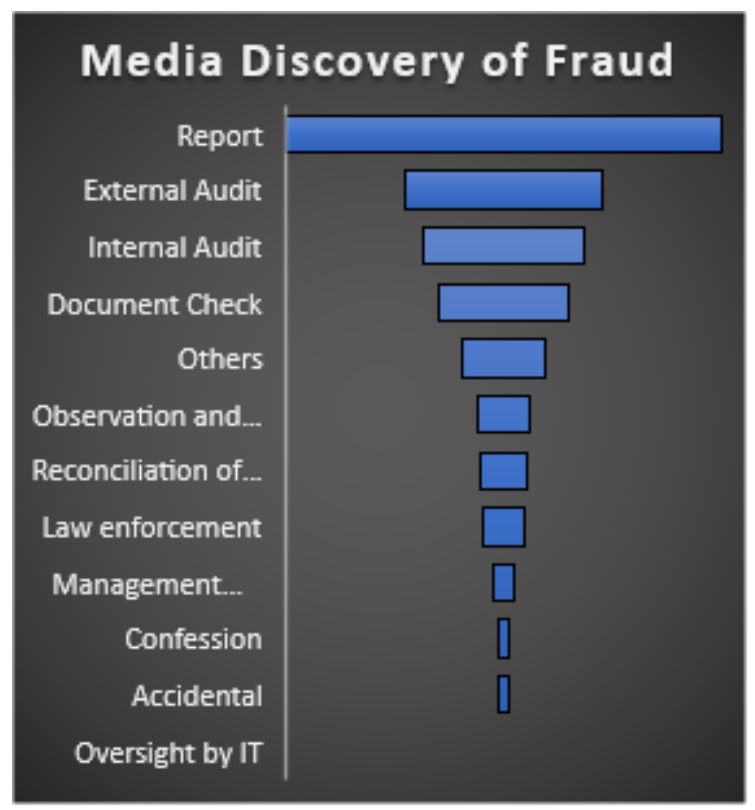

Fig. 5. Media Discovery of Fraud, EY (2016).

Answering picture 5 which states that the report is the largest media found fraud, then the picture explains that the source of the report is from the company's own employees. This is also the same as RTTN published by ACFE which states that the main source of fraud is employees.

Respondents stated that the most common fraud in Indonesia is corruption. Respondents also stated that the biggest loss was in corruption with the average loss of each corruption being IDR 100 million to IDR 500 million rupiah per case. Acts of corruption can be immediately detected in a period of less than 12 months ( $<1$ year). The most important media to detect fraud is through reports, which come from employees of the company's internal parties themselves.

Profile of perpetrators of fraud, most are at the age of 36-45 years. At that age, the perpetrators occupy positions as middle management or manager level. The educational background of the corruptors, most are at the Bachelor and Masters level. Fraud happens to employees with tenure of more than 10 years, this is because they are familiar with the 
condition of the company so they can easily commit fraud. It was also found that the motivation of the perpetrators to cheat was the desire for extravagant life style so that they were driven to steal company money to meet their needs. In addition, the majority of fraud perpetrators have also never been convicted. Some of the results of this study reflect that fraud in Indonesia is not much different from the results of surveys conducted globally.

\section{Conclusion}

Based on the analysis in research, then some conclusions that can be taken are as follows. Information technology can be a managerial decision to prevent fraud in the company. This is proven that developed companies, especially in developed countries, use supervision not only as a leader but also technology that can automatically detect fraud and is useful as a step to prevent fraud in companies. Corporate governance is still lacking in Indonesia and other developing countries, making the level of supervision at the company does not run optimally so that the potential for fraud is still quite large. This research contributes to fill the void level of supervision in companies in Indonesia that are still experiencing fraud, so the solution in supervision is to maximize the role of information technology in companies in Indonesia.

\section{References}

1. Y. Zhuang, J. Electron. Commer. Res. 6, 146 (2005)

2. J. L. Bierstaker, R. G. Brody, and C. Pacini, Manag. Audit. J. 21, (2006)

3. T. E. McKee, Manag. Audit. J. 21, (2006)

4. H. Grove and E. Basilico, Int. Stud. Manag. Organ. 38, 10 (2008)

5. D. Janvrin, J. Bierstaker, and D. J. Lowe, Account. Horizons 22, 1 (2008)

6. M. Krambia-Kapardis, C. Christodoulou, and M. Agathocleous, Manag. Audit. J. 25, (2010)

7. E. W. T. Ngai, Y. Hu, Y. H. Wong, Y. Chen, and X. Sun, Decis. Support Syst. 50, 559 (2011)

8. W. Zhou and G. Kapoor, Decis. Support Syst. 50, 570 (2011)

9. A. Sharma and P. K. Panigrahi, Int. J. Comput. Appl. Pplications 39, (2012)

10. S. Chen, Y.-J. J. Goo, and Z.-D. Shen, Sci. World J. 2014, (2014)

11. S. S. Halbouni, Int. J. Audit. 19, 117 (2015)

12. S. S. Halbouni, N. Obeid, and A. Garbou, Manag. Audit. J. 31, 589 (2016)

13. D. Karyono, Forensic Fraud (Andi Offset, Yogyakarta, 2013)

14. M. Affandi, Teknologi Informasi \& Komunikasi Dalam Pendidikan (Penerbit YNHW, 2018)

15.Z. Rezaee, Crit. Perspect. Account. 16, 277 (2005)

16. M. D. Beneish, Financ. Anal. J. 55, 24 (1999)

17. T. Suryanto, Eur. Res. Stud. J. 19, 18 (2016)

18. T. Sutabri, Pengantar Teknologi Informasi (Andi Offset, Yogyakarta, 2014)

19. B. Sutarman, Pengantar Teknologi Informasi (Bumi Aksara, Jakarta, 2012)

20. H. Khan, in Int. Conf. E-Business, Manag. Econ. (2011), pp. 1-5

21. A. Cadbury, Report of the Committee on the Financial Aspects of Corporate Governance (Gee, 1992) 
22. O. OECD, Contaduría y Adm. (2004)

23. Komite Nasional Kebijakan Governance (KNKG), Pedoman Sistem Pelaporan Pelanggaran-SSP (Whistleblowing System WBS) (Jakarta, 2008)

24. A. W. Tunggal, Kecurangan Dan Pencegahan Kecurangan Fraud and Fraud Preventions (Harvarindo, Jakarta, 2016)

25. D. R. Cressey, (1953)

26. R. K. Yin, Evaluation 19, 321 (2013)

27. P. Baxter and S. Jack, Qual. Rep. 13, 544 (2008)

28. Association of Certified Fraud Examiners (ACFE), SURVAI FRAUD INDONESIA 2016 (Jakarta, 2017) 